\title{
1980 Gulf of Alaska sampling program, eastern Gulf of Alaska
}

McCoy, Scott, Jr., and Amoco Oil Co.

GMC DATA REPORT 454

This GMC data report from the Amoco Heritage collection has been made available through funding from the FY2018 USGS National Geological and Geophysical Data Preservation Program, Grant Number G18AP00054. This project report is presented in its original format and has not been reviewed for technical content or for conformity to the editorial standards of DGGS. It should not be used or cited as reviewed data.

2019

State of Alaska

Department of Natural Resources

Division of Geological \& Geophysical Surveys

GEOLOGIC MATERIALS CENTER
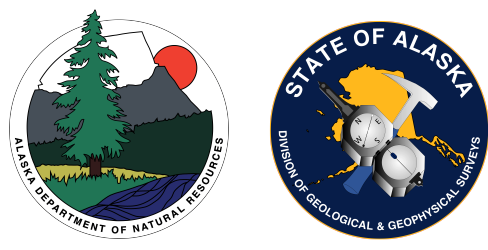


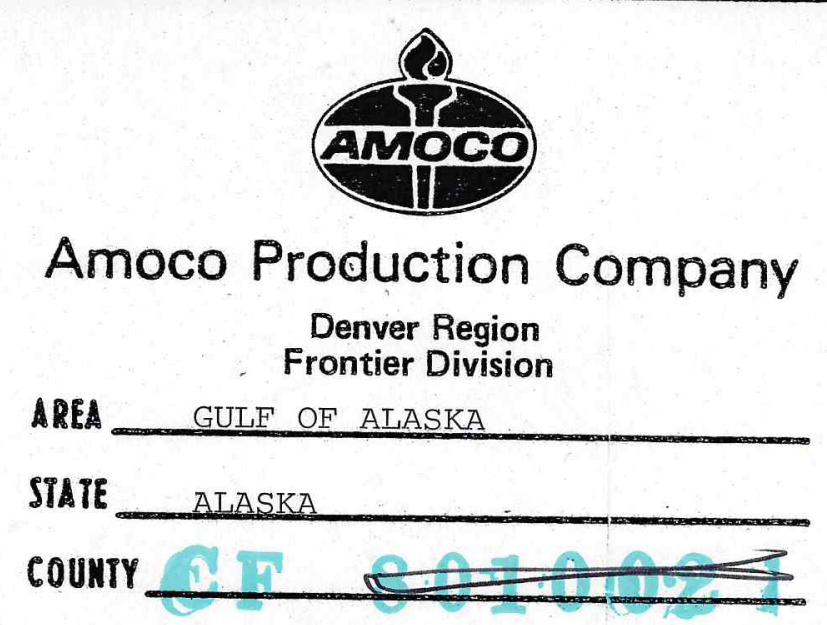

SUBJEGT 1980 Gulf of Alaska Sampling Program

Eastern Gulf of Alaska

Dafe $\frac{\text { Geological Report }}{\text { October, } 1980}$ So Nott McCoy, Jr.

EMCLOSURES

Icy Point Measured Section

Megafossil ages and environments (previous collection)

3. Megafossil ages and environments (1980 collections)

4. Source rock analyses 


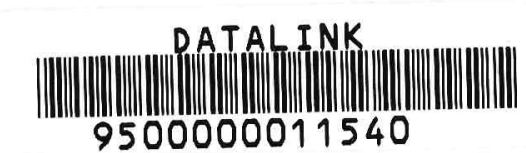

October, 1980

Denver Region Geological Report

No. FR 14-80

1980 Gulf of Alaska Sampling Program

Eastern Gulf of Alaska

CF 801002

INTRODUCTION

CONCLUSTONS

ENCLOSURES

DISCUSSION

Author: S. MCCOY 
INTRODUCTION:

The presence of source rocks with a petroleum generating capability within the Yakutat OCS Sale 55 area scheduled for sale in October 1980 is problemmatical. Samples dredged from the Eocene of the continental slope south of the sale area were indicative of a poor source for dry gas, although onshore outcrop samples from the Samovar Hills northwest of the sale area were indicative of oil and gas-light oil, also from Eocene rocks. The best analyses for oil source potential in the Gulf of Alaska come from

Kayak Island many miles to the west. It is conceivable that this rich source was deposited in a restricted basin which trended to the southeast through the sale area (Figure 2). The only outcrop of strata older than middle Miocene (Yakataga Formation) to occur onshore southeast of Malaspina Glacier crops out at Icy Point in Glacier Bay National Monument. Detailed preparation for the sale revealed that these strata of the Topsy Formation, upper oliogocene to lowermost Miocene in age according to the U.S.G.S. and therefore equivalent to the Poul Creek Formation had never been sampled or analyzed for hydrocarbon source potential. Management felt that sampling of these rocks was important and a one day program was mounted on september 5, 1980 by Scott McCoy and Randy Kubes of the Denver Region office.

\section{CONCLUSIONS:}

Preliminary geochemical analyses suggest that the rocks are nonsource to marginally poor sources for dry gas and thermally immature. This does not negate the possibility that the restricted basin with petroleum source rocks is present offshore between this point and the submarine exposures of the continental slope. Paleontologic studies for age control proved to be inconclusive.

\section{ENCLOSURES:}

\section{Icy Point Measured Section}

2. Megafossil ages and environments (previous collection)

3. Megafossil ages and environments (1980 collections)

4. Source rock analyses

\section{DISCUSSION:}

Tertiary rocks crop out in the intertidal zone along the coast on all sides of the Icy Point peninsula (Figure 1) at the entrance to Palma Bay, north of Cross Sound. Structurally they form the southwestern limb of an overturned anticline with an axis striking northwest-southeast. At Icy point the northern limb of the structure is missing and the Fairweather Fault, a regional. strike-slip fault, cuts across the structure. The fault is not exposed, but lies buried beneath the alluvium of the Kaknau Creek Valley.

The Icy Point Measured Section lies along the east and south sides of the peninsula and comprises 6621 feet of total section. The lower 2845 feet are predominantly siltstone and mudstone and comprise the Topsy Formation outcrop. The remainder of the outcrop is the Yakataga Formation. Sampling conditions were not ideal during the collection of the 1980 samples (in-coming tide and light drizzle), but a total of sixteen source rock samples were obtained from the Topsy Formation (see enclosure l for measured section and sample horizons). These samples were then cut in Denver for paleontology.

Due to the northwestern structural grain, similar rocks are exposed along the western side of the perinsula. These are, however, predominantly Yakataga Formation. Three additional spot samples were collected from the Yakataga (samples 17, 18 \& 19: the first two for source rock analysis and the last for sandstone lithology), and one (sample 20) from the Topsy Formation. 


\section{DISCUSSION (Continued)}

The samples cut for paleontology were processed and then examined by Earl Armstrong for foraminifera and Dave Wall for palynology. No foraminifera were found. The samples were observed to be highly slickensided. Deformation associated with the close proximity of the Fairweather Fault possibly destroyed the foraminifera originally present. Weathering in the intertidal zone may also have been a contributing factor in their removal. A few megafossil fragments were observed. Palynological studies also proved to be inconclusive. No age diagonostic forms were found, but those present suggest a possible age younger than that of the offshore dredge samples (upper Eocene). Organic material was almost entirely structured and at a thermal maturation state of 4 .

Megafossils, predominantly irregular echinoids, were collected at several horizons; but have not been studied to date. Their analysis will be added as enclosure 3 of this report when completed. Megafossil studies with age and environmental interpretations by scott McCoy of collections made in prior years from the upper part (Yakataga Formation) of the measured section is included as enclosure 2, Magafossils were also collected with the grab samples from the west side of the peninsula.

A U.S.G.S. collection (D186 $=75 \mathrm{APr} 43-\mathrm{D}=$ M6527) from the northermost outcrop along the west side of the peninsula (Location: isolated outcrop 3-1/2 miles north of Icy Point, 2400 feet south, 100 feet east of the northwest corner of Section 10, T4OS, R50E, Mt. Fairweather B-4...E \& R 12/11/75) contains the following fauna: Echinophoria apta; Colus sp.; Calyptraea sp.; Lucinoma acutilineata; Polinices ramonensis; Neptunea sp. (possible kannoi). The presence of $\mathrm{E}$. apta indicates an upper oligocene of lowermost miocene age for the Topsy Formation and is the only absolute proof for the equivalence of these strata with the Poul Creek Formation of the Yakataga area.

Detailed source rock studies and thermal evolution analysis for the samples are not yet available. When completed these will be added as enclosure 4 of this report. Preliminary results for eight samples indicate organic carbon content of 5 to $1.2 \%$, nonsource to poor source quality, and a generative capability of dry gas.

Thermal evolution analyses for two samples were as follows:

\begin{tabular}{|c|c|c|c|c|}
\hline SAMPLE & $\begin{array}{l}\text { VOLATILE } \\
\text { HC ppm }\end{array}$ & $\begin{array}{l}\text { GENERATED } \\
\text { HC Ppm }\end{array}$ & $\begin{array}{l}\text { THERMAI } \\
\text { MATURITY } \\
\end{array}$ & SOURCE ROCK POT. \\
\hline SM 80-12 & 40 & 248 & immature & nonsource \\
\hline SM $80-15$ & 29 & 645 & immature & marginally poor \\
\hline
\end{tabular}




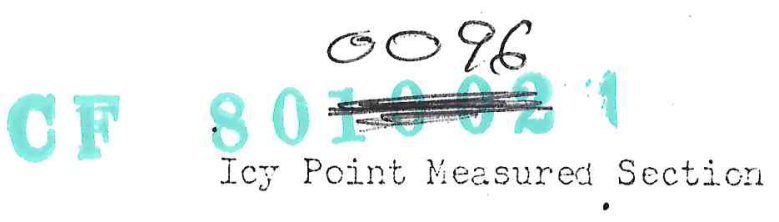

IP 44-70 Yakataga Formation - collection from unit 34, about 41450 feet above the base of the measured section.

Bivalvia: Solene sp. (fragnents)

Age ard Environment: Katerial nondiagnostic for age or tempenature determination, inner neritic (water depth intertidal (rud flat) to 80 meters).

IP 4IB-70 Yakataga Formation - collection from unit 40 , about 4800 feet above the base of the measured section.

Sivalvie: brtilus eculis Iinné

Echinoidea: unidentified clypaesteroid echinoid

Age and Environment: Katerial nondiagnostic for age or temperature determination, intertidal.

IP 4lf-70 Yaketsega Fomation -- collection from unit 41 about 4850 feet. above tre base of the measured section.

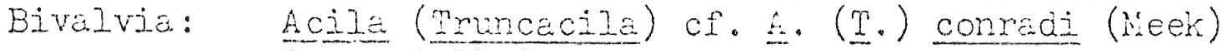
Crassatelie? SD.

Echinoidea: unidentified echinoid fragments Age and Environnent: Kicile or late Uiccene (middle Niocene by inference), inner neritic (water depth probably 10 meters or less), warm temperate?

IP 41-70 Yakataga Formation - collection from the top of unit 42 about 4950 feet above the base of the measured section.

Bivalvia: Acile (iruncecila) conradi (kiek)

Gastropoda: Colus cí. C. jordan Dall

gastropod (indeteminate)

Age and Enviroment: Widile or late Miocene (middle Yiccene by inference), material nondiagnostic for water depth (deeper than 20 meters) or temperature determination.

IP 4OD-70 Yakataga Formation - collection from unit 43 about 4960 feet above the base of the measured section.

Bivalvia: $\quad$ cila cf. $\dot{\text { A }}$ gettrsburensis (Reagan) Macona inquinate (Deshayes) bivalve (indeterminate)

Age and Environment: Midile Mocene? (L. gettvsburgensis is typical of the late Oligocene and early liocene and has not been found in younger strata. The presence of a single specimen which does not appear to be reworked and the associated forms which are no oldor than middle kiocene suggust a minimum age of middle liocene), meterial nondiagnostic for water depth or temperiture determination. 
IP 400-70 Yakataga Formation - collection from unit 43 about 5010 feet above the base of the measured section.

Bivalvia: Macoma sp. (fragment)

kyct sp. (frigment)

Acila (Iruncacila) conradi (Week)

Solen sp.

Age and Environment: Middle or late Wiocene (middle Viocere by inference), inner neritic (water depth 10 to 40 meters), material nondiagnostic for temperature detemination.

IP 40A-70 Yakataga Formation - collection from unit 43 about 5210 feet above the base of the measured section.

Bivalvia: Spisula (Mactromeris) albarja (Conraci)

Age and Environment: Widdle líiocene (by inference), inner neritic (water depth intertidal to 50 meters), material nondiagnostic for temperature determination.

Ip 39-70 Yakataga Formation - collection from 100 feet below the top of unit 45 about 5525 feet above the base of the measured section.

Bivalvia: liva truncata Iinne

Age and Enviroment: Material nondiagnostic for age (middle Hiocene or younger) or temperature determination, inner neritic (water depth 4 to 35 meters).

IP 37A-70 Yakataga Formation - collection from unit 47 about 5730 feet above the base of the measured section.

Bivalvia: Thyasira bisecta Conrad

Gastropoda: Colus sp.

Age and Environment: Material nondiagnostic for age, water depth (deeper than 20 meters) or temperature determination.

IP 37-70 Yakataga Formation - collection from the base of unit 49 about .5760 feet above the base of the measured section. Bivalvia: Acila (Truncacila) emoirensis Hove

Gastropoda: Volutopsius cf. V. stefanssoni Dall

Echinoidea: clypaeasteroid echinoid fragments (indeterminate) Age and Environment: Late Niocene or early Pliocene (late Mifocene by inference), inner neritic (water depth very shallow, probably around 10 meters), cool temperate.

IP 36c-70 Yakataga Formation - collection from 20 feet above the base of unit 50 about 5.933 feet above the base of the measured section.

Bivalvia: Acila (Truncacila) emoirensis Howe

Age and Environment: Late Miocene (by inference), material. nondiagnostic for water depth or temperature determination. 
IP 36B-71 Yakataga Formation - collection from 30 feet above the base of unit 50 about 5843 feet above the base of the measured section.

Bivalvia: Acila (Truncacila) empirensis Howe Thyasira bisecta Conrad Tacoma inquineta Deshayes

Brachiopoda: Terebratalia sp. (internal mold)

Age and Environmont: Lito Miocene (by inserence), material nondiagnostic for depth detemination (deeper than 10 meters), cool temperate.

SIPOI 50-81 Yakataga Formation - collection from 81 feet above the base of unit 50 about 5894 feet cbove the base of the measured section.

Gastropoda: Volutonsius cf. V. stefenssoni Dall

ige and Environment: Late Mocene (by inference), material nondiagnostic for water depth or temperature determination.

IP 36A-71 Yakataga Formation - collection from 130 feet above the base of unit 50 about 5944 feet above the base of the measured section.

Bivalvia: Muculana aff. N. chehalisensis (Weaver)

Thyasira bisecta Conrad

Acjla (Truncacila) empirensis Howe

Macone inquinata Deshayes

Gastropoda: Natica (Cryptonatica) sp. Volutoosius cf. V. Stefanssoni Dall Megasurcula sp.

Age and Environment: Late Niocene (by inference), material nondiagnostic for water depth determination (the forms have a minimun depth of about 20 meters. Because of the close proximity of IP 36, I would infer that sedimentation took place in about 20-25 meters of water), cool temperate.

IP 36--71 Yakataga Formation - collection from 20 feet below the top of unit 50 about 6024 feet above the base of the measured section.

Bivalvia: Spisula (Mactromeris) albaria (Conrad)

Age and Environment: Iate Niocene (by inference), inner neritic (water depth intertidal to 50 meters), cool temperate.

IP 35-71 Yakataga Formation - collection from unit 52 about 6090 feet above the base of the measured section.

Bivalvia: Nacoma sp. bjvalve (indeterminate fragments)

Age and Environment: Indeterminate

IP 34-71 Yakataga Formation - collection from the upper 40 feet of unit 53 about 6200 feet above the base of the measured section. 
Bivalvia: Spisula (Nactromerj.s) albaria (Conrad) Macrocallista sp.

Echinoidea: Scutellaster sp.

hge and Environment: Early Pliocene, inner neritic (water depth intertidal to 10 meters), cool temperate.

SIPO1 54 Yakataga Formation - collection from unit 54 about 6300 feet above the base of the measured section.

Bivalvia: Acila (Truncacila) empirensis Howe

Nalacostraca: crab (indeterminate fragment)

Age and Enviroment: Early Pliocene, inner neritic (by inference), cool temperate.

Note: The fossil collections below 5760 feet (IP 37-70) all have ar age range of middle or late lifocene and those above late Niocene or early Pliocene. In all cases I have assumed the older age to be correct because of the occurrence of the "primitive" A. Gettysburgensis in IP 4OD-70. The PIiocene age cali at the top of the section is based on the presence of the clypaeasterid echinoid Scutellaster which is considered to be a Pliocene form in California. 
District: Lituya

Locotion: Sec 13,23,24 T4OS R5OE CRM

Quadrangle. Mt. Fairweather (B.4) 1:63,360 Aeriol Photo.

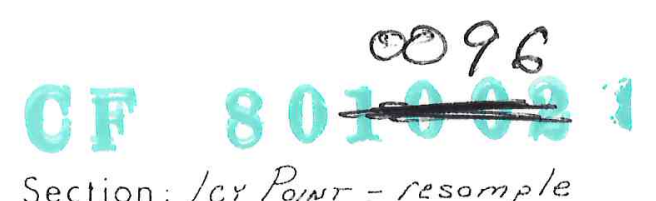

Pore

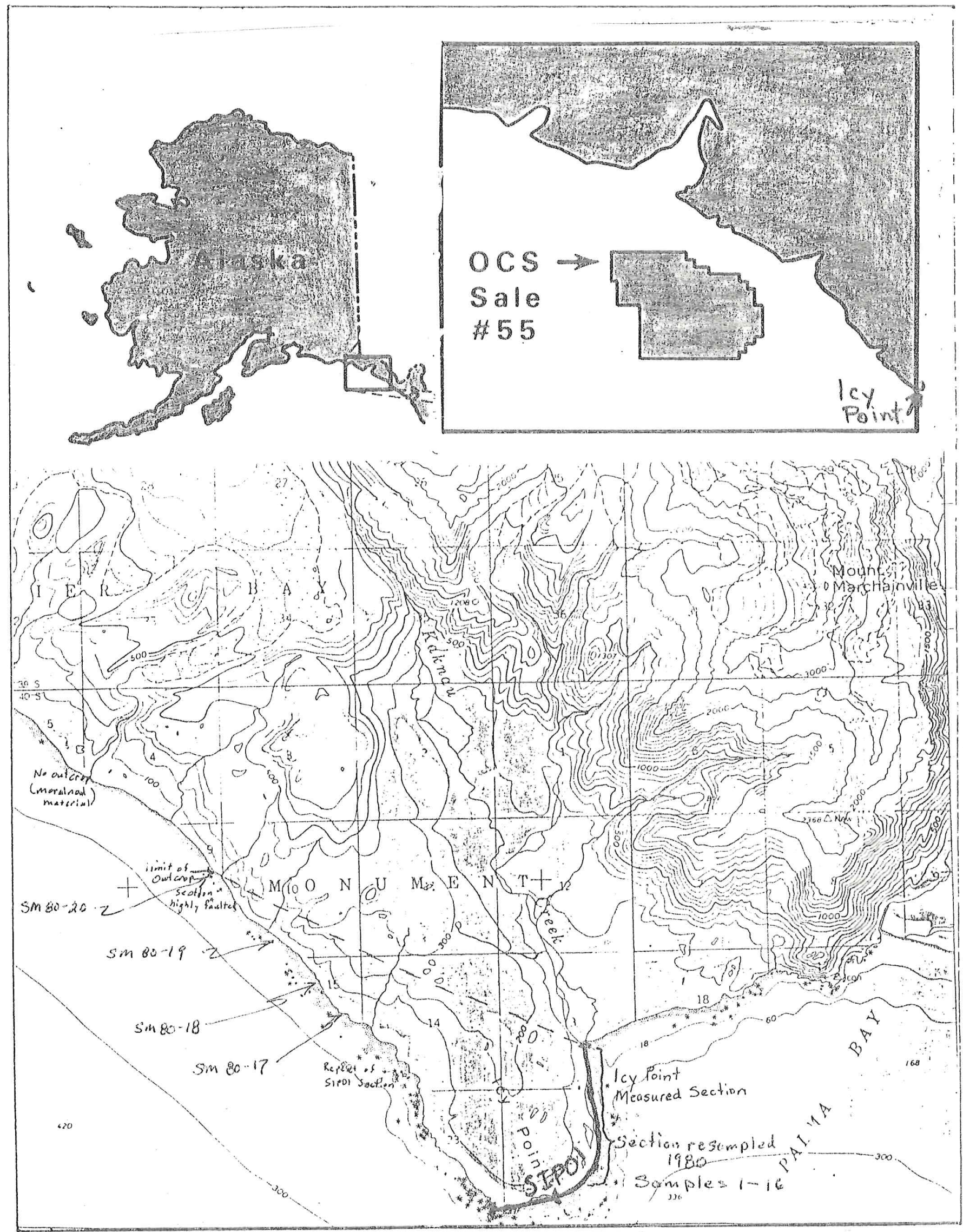

Scale

$0 \quad 1 \mathrm{mi} \cdot 2 \mathrm{mi}$ 


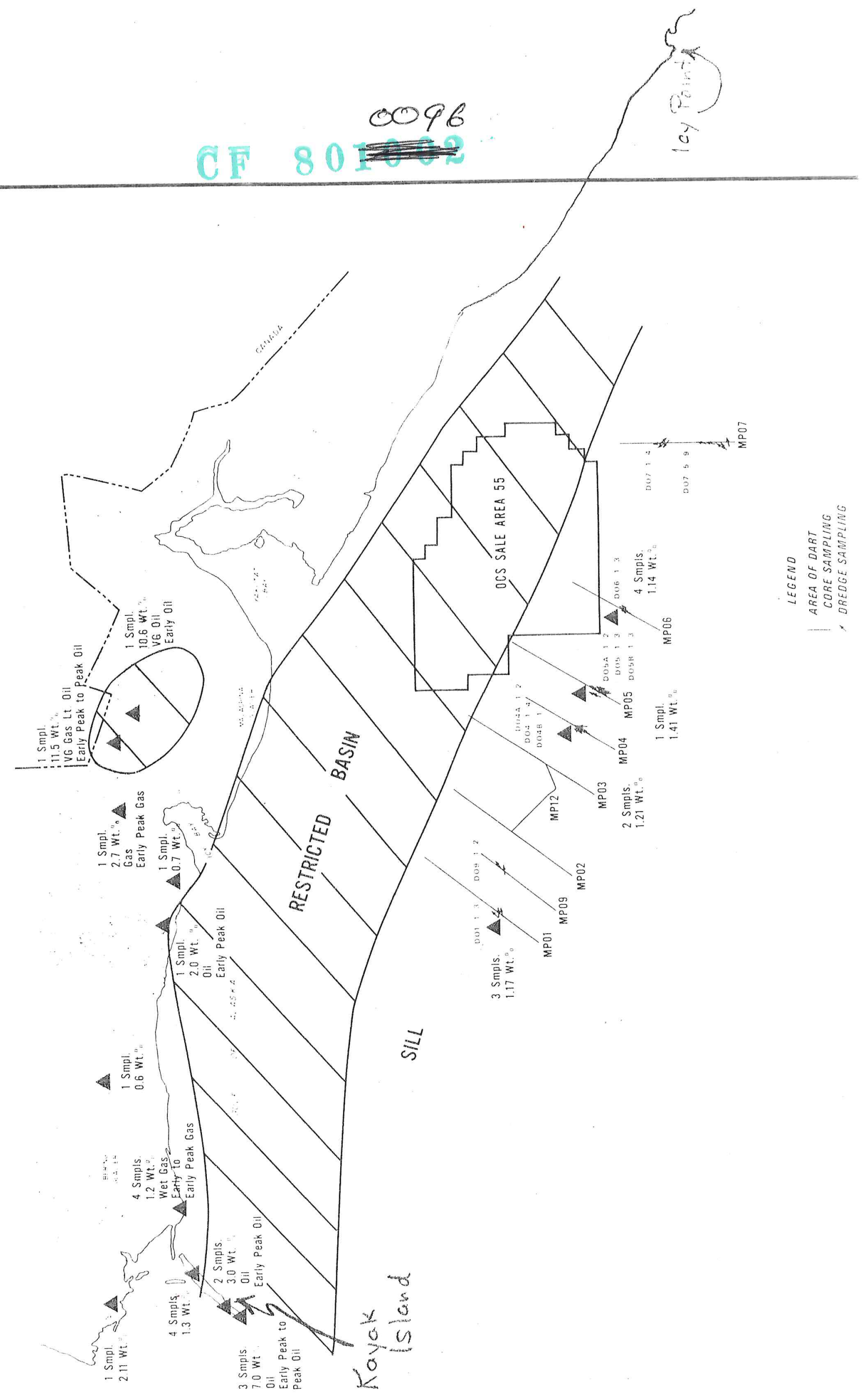

FIGURE 2

Possible Zone of Enriched Petroleum Source Rock 